\title{
THE ILLUSTRATION GROW OF CONTAMINANT FUNGI AT WHITE BREAD BASED ON TEMPERATURE AND HUMIDITY
}

\author{
Niken Saymona Sari Susanti ${ }^{1 *}$, Maulin Inggraini ${ }^{2}$, Reza Anindita ${ }^{3}$ \\ 1. Diploma of Medical Laboratory Technology, Stikes Mitra Keluarga, Bekasi-Indonesia \\ 2. Diploma of Medical Laboratory Technology, Stikes Mitra Keluarga, Bekasi-Indonesia \\ 3. Diploma of Medical Laboratory Technology, Stikes Mitra Keluarga, Bekasi-Indonesia
}

*Correspondence: Niken Saymona Sari Susanti | STIKes Mitra Keluarga | Nsaymonaa@yahoo.com

\begin{abstract}
Introduction: Food is a basic need for every living creature. Bread is one of the processed foods that is consumed by many people as a staple food substitute for rice. The shelf life of white bread is usually not more than a week or even just three days. The appearance of bread that is not suitable for consumption is indicated by the appearance of discoloration on the bread due to being overgrown with fungus. The fungus that grows on white bread can produce mycotoxins during the storage process. Food poisoning can cause symptoms such as nausea, vomiting, and diarrhea.

Method: The purpose of this study was to determine the average percentage of white bread covered with contaminant fungi based on temperature and humidity. The method used is descriptive.

Results: The results showed that white bread overgrown with contaminant fungi by steaming and not steaming which was placed at room temperature grew faster than white bread placed at refrigerator temperature. At room temperature $\left(27^{\circ} \mathrm{C}-30^{\circ} \mathrm{C}\right)$, contaminant fungi began to grow on the seventh day on white bread 1 and on the fourth day on white bread 2 with the steamed treatment, while for the non-steamed treatment the contaminant fungi began to grow on the fifth day. At refrigerator temperature $\left(13^{\circ} \mathrm{C}-16^{\circ} \mathrm{C}\right)$, white bread with steamed and unsteamed treatment was not covered with contaminant fungi.

Conclusion: The conclusion of this study is that white bread overgrown with contaminant fungi at room temperature with steam treatment was $3.33 \%$ on the fourth to fifth day, and $66.6 \%$ on the seventh day. Bread covered with contaminant fungi at room temperature with treatment not steamed as much as $3.33 \%$ on the fifth to the seventh day. Researchers hope that future researchers can conduct this research by adding a microscopic examination method.

Keywords: Bread, Not Steamed, Refrigerator Temperature, Room Temperature, Steamed.
\end{abstract}

Received November 25, 2021; Accepted December 30, 2021

\section{INTRODUCTION}

Carbohydrates have a role as the main source of energy. Bread is an example of a food that contains carbohydrates. Currently, bread is consumed by Indonesian people as a basic need. Bread can be used as a substitute for rice because its nutritional content is not inferior to rice (Fendiyanto \& Satrio, 2020).

Foodstuffs can be damaged microbiologically by microbial contamination through the air, dust, or hands that enter the food. Microbes can cause food spoilage and are harmful to the body because they can produce toxins. Microbes in foodstuffs can change the composition of foodstuffs by hydrolyzing starch and cellulose into smaller fractions, hydrolyzing fats and causing rancidity, causing sugar fermentation and breaking down protein into ammonia, resulting in a foul odor (Arini, 2017).

Food poisoning can cause several symptoms such as nausea, vomiting, and diarrhea. Nausea, vomiting, and diarrhea can last for one or three days, depending on the type of poison and the level of contamination that occurs (Arini, 2017). One type of fungus that grows on bread is Aspergillus flavus. Aflatoxin is a mycotoxin found in the fungus Aspergillus flavus. Mycotoxin contamination in food can cause problems for human health because it is toxic to the kidneys, liver, reproductive system and can cause cancer (Broto, 2018).

World Health Organization (2019) stated that more than 23 million people experienced food poisoning and an estimated 4,700 people died. In 2017, the Center for Drug and Food Medicine (BPOM) recorded 53 cases of Extraordinary Events (KLB) of food poisoning throughout Indonesia. It was recorded that 5293 people were exposed to it, while 2041 people were reported to be sick, and 3 people died. One of the causes of food poisoning cases due to microbiology is the activity of microbial types of fungi. In 2018 the Ministry of Health reported that outbreaks of food poisoning still occur in Java, the highest province of food 
poisoning outbreaks in 2017 was West Java with 25 cases of food poisoning

Bread is made from wheat flour which contains starch. Fungi can hydrolyze the starch content in bread into simple sugars. Simple sugars are needed by mushrooms as the main source of nutrition. Bread requires fungi for the process of bread making and bread spoilage. Storing bread for a long time can lead to mold growth. Fungi that are often found in bread spoilage are Rhizopus stolonifer, Penicillium sp, Mucor sp, Geotrichum sp, and Aspergillus sp (Mizana et al., 2016)

Research conducted by Mizana et al (2016) stated that the growth of the fungus Aspergillus sp. in three samples of bread sold in the city of Padang. Bread stored at room temperature $\left(25^{\circ} \mathrm{C}-28^{\circ} \mathrm{C}\right)$ grew Aspergillus sp on the third day as much as $33.3 \%$ in one sample of white bread and the other two samples only grew mushrooms on the fourth day as much as $67.7 \%$. Bread that was stored at a refrigerator temperature $\left(10^{\circ} \mathrm{C}-15^{\circ} \mathrm{C}\right)$ was $100 \%$ overgrown with Aspergillus sp fungus on the fifth day.

Research conducted by Sulastina (2020) stated that there was 6.2\% growth of Aspergillus sp fungus in 1 sample of white bread from 16 samples of white bread sold in Traditional Markets, $6.2 \%$ growth of Aspergillus sp fungus in 1 sample of white bread. white bread had skin from 16 samples of white bread based on the type, and 6.2\% growth of Aspergillus sp fungus on 1 piece of white bread before 2 days of the expiration of 8 pieces of white bread samples based on the expiration period.

Based on previous research regarding the growth of contaminant fungi in white bread, no research has been done with the treatment of white bread by steaming and not steaming. On this basis, researchers are interested in conducting research on "Description of the growth of contaminant fungi on white bread based on temperature and humidity".

\section{METHOD}

This type of research is descriptive. The research was carried out in March 2021. The location of the research was carried out at the Microbiology Laboratory of the DIII Technology Study Program, Medical Laboratory, Mitra Keluarga College, East Bekasi. The tools used in this research include masks, handscoons, plastic clips, digital thermo-hygrometers, stoves, steamers, timers. The materials used in this study were plain bread and water.

Fresh bread was taken as many as 12 pieces with 3 brands of bread. 4 pieces of bread 1, 2, and 3 were taken each and then put into plastic clips that have been labeled. Bread is done in 2 ways of treatment, namely steamed and not steamed. Steamed bread for 15 minutes. The bread was placed at room temperature $\left(27^{\circ} \mathrm{C}-30^{\circ} \mathrm{C}\right)$ and refrigerator temperature $\left(13^{\circ} \mathrm{C}-16^{\circ} \mathrm{C}\right)$ each with 6 samples, 3 samples steamed, and 3 samples not steamed. The bread was observed macroscopically for 7 days by looking at how many days the bread experienced the growth of physical contaminants such as changes in the color of the bread.

The sample in this study was 3 brands of white bread. The criteria in this study are freshly produced bread and have the same expiration date. The data of white bread with contaminant fungus on bread was analyzed descriptively qualitatively.

\section{RESULTS}

This research was conducted on white bread samples with steamed and unsteamed treatment which were stored for seven days at room temperature and refrigerator temperature. The amount of white bread needed in this study was 12 pieces with 3 different brands of white bread. The results of observations of temperature and humidity on white bread that were stored for 7 days can be seen in table 1 .

Table 1. Results of Observation of Temperature and Humidity

\begin{tabular}{lllllllll}
\hline \multirow{2}{*}{\multicolumn{1}{c}{ Observation }} & \multicolumn{7}{c}{ Days } \\
\cline { 2 - 9 } & \multicolumn{1}{c}{$\mathbf{2}$} & $\mathbf{3}$ & $\mathbf{4}$ & $\mathbf{5}$ & $\mathbf{6}$ & $\mathbf{7}$ \\
\hline Room temperature $\left({ }^{\circ} \mathbf{C}\right)$ & 29.9 & 28.7 & 27.4 & 28.5 & 28.1 & 27.9 & 29.4 \\
Refrigerator Temperature $\left({ }^{\circ} \mathbf{C}\right)$ & 15.5 & 15.1 & 13.8 & 15.3 & 13.5 & 13.3 & 13.1 \\
Humidity (\%) & 71 & 78 & 81 & 77 & 79 & 80 & 77 \\
\hline
\end{tabular}

Temperature and humidity are factors that affect mold growth. The optimal temperature for fungal 
growth is $25^{\circ} \mathrm{C}-30^{\circ} \mathrm{C}$. The optimal humidity for fungal growth is $60 \%-88 \%$ ((Khasanah et al., 2013). Based on table 1, the results of the storage of white bread at room temperature for 7 days are $27^{\circ} \mathrm{C}-30^{\circ} \mathrm{C}$, this temperature is included in the optimal temperature for fungal growth. At room temperature $\left(27^{\circ} \mathrm{C}-\right.$ $\left.30^{\circ} \mathrm{C}\right)$, contaminant fungus in white bread grows faster than at refrigerator temperature $\left(13^{\circ} \mathrm{C}-16^{\circ} \mathrm{C}\right)$. The moisture yield of white bread for 7 days is $71 \%-81 \%$, the humidity is included in the optimal humidity for mold growth.

Bread brands 1, 2, and 3 were observed at room temperature. A total of 3 pieces of bread with steamed treatment and 3 pieces of bread with non-steamed treatment. The results of observations of the growth of contaminant fungi on white bread with steamed treatment stored at room temperature can be seen in table 2 . The results of observations of the growth of contaminant fungi on white bread with treatment not steamed and stored at room temperature can be seen in table 3 .

Table 2. Observation of the growth of contaminant fungi on white bread with steamed treatment stored at room temperature

\begin{tabular}{|c|c|c|c|c|c|c|c|}
\hline \multirow{2}{*}{ Breads } & \multicolumn{7}{|c|}{ Days } \\
\hline & 1 & 2 & 3 & 4 & 5 & 6 & 7 \\
\hline 1 & - & - & - & - & - & - & $\sqrt{ }$ \\
\hline 2 & - & - & - & $\sqrt{ }$ & $\sqrt{ }$ & $\sqrt{ }$ & $\sqrt{ }$ \\
\hline 3 & - & - & - & - & - & - & - \\
\hline
\end{tabular}

Based on table 2, it is known that the contaminant fungus on white bread with steamed treatment stored at room temperature obtained observations, namely on white bread 1 contaminant fungus began to grow on the seventh day, on white bread 2 contaminant fungi began to grow on the fourth day, and on bread tasteless to the 3 contaminant fungi did not grow at all for seven days.

Table 3. Observation of the growth of contaminant fungi on white bread with non-steamed treatment stored at room temperature

\begin{tabular}{cccccccc}
\hline \multirow{2}{*}{ Breads } & \multicolumn{8}{c}{ Days } \\
\cline { 2 - 8 } & $\mathbf{1}$ & $\mathbf{2}$ & $\mathbf{3}$ & $\mathbf{4}$ & $\mathbf{5}$ & $\mathbf{6}$ & $\mathbf{7}$ \\
\hline $\mathbf{1}$ & - & - & - & - & - & - & - \\
$\mathbf{2}$ & - & - & - & - & $\sqrt{ }$ & $\sqrt{ }$ & $\sqrt{ }$ \\
$\mathbf{3}$ & - & - & - & - & - & - & - \\
\hline
\end{tabular}

Based on table 3, it is known that the contaminant fungus on white bread with unsteamed treatment that was stored at room temperature obtained observations, namely on white bread 1 and white bread 3 contaminant fungi did not grow at all for seven days, on white bread 2 contaminant fungi began to grow on the fifth day.

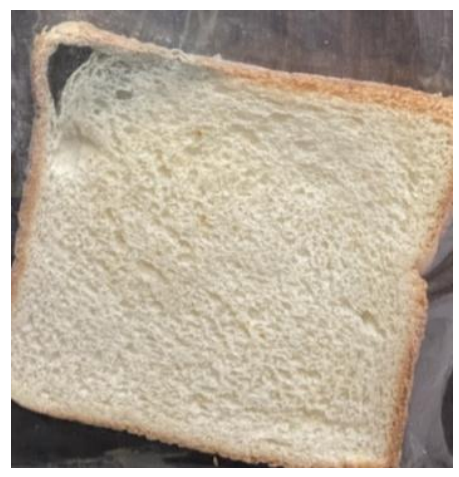

(a)

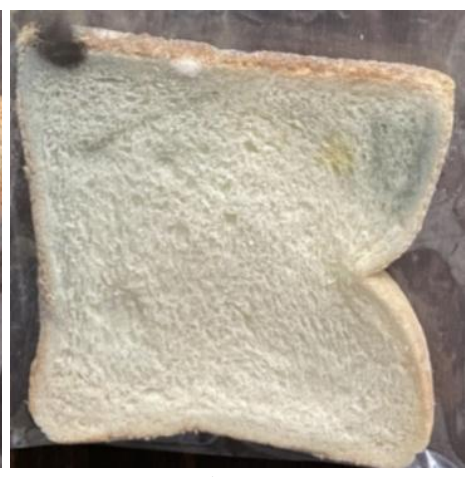

(b)

Figure 1. (a). Bread 1; (b). Bread 2 covered with contaminant fungus by steaming and stored at room 
temperature

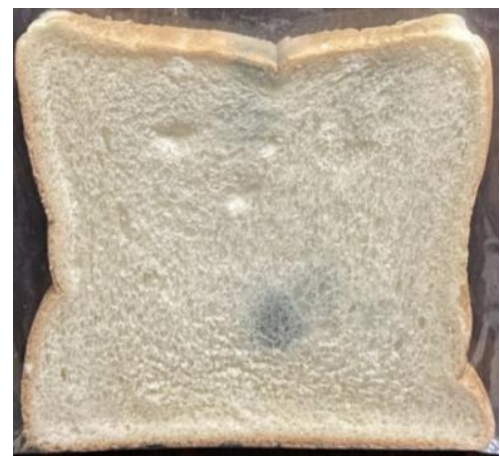

Figure 2. Bread 2 overgrown with contaminant fungus with non-steamed treatment stored at room temperature

Figure 1 is a picture of white bread 1 and 2 overgrown with contaminant fungi on day 7 by steaming and stored at room temperature. Figure 2 is a picture of white bread 2 overgrown with contaminant fungi on the seventh day with the treatment not being steamed and stored at room temperature. Bread 1 with steam treatment on the seventh day began to grow contaminant mushrooms which were marked by gray spots. Bread 2 with steam treatment on the fourth day began to grow contaminant mushrooms which were marked by white spots, then until the seventh day green, black, and gray appeared. Bread 2 with non-steamed treatment on the fifth day began to be marked by the growth of contaminant fungi which was indicated by the presence of white and green spots, then until the seventh-day a gray color appeared.

Bread brands 1,2, and 3 were observed at refrigerator temperature. A total of 3 pieces of bread with steamed treatment and 3 pieces of bread with non-steamed treatment. The results of observations of the growth of contaminant fungi on white bread with steamed treatment stored at refrigerator temperature can be seen in table 4 . The results of observations of the growth of contaminant fungi on white bread with treatment not steamed and stored at refrigerator temperature can be seen in table 5 .

Table 4. Observation of the growth of contaminant fungi on white bread by steaming treatment stored at refrigerator temperature

\begin{tabular}{cccccccc}
\hline \multirow{2}{*}{ Breads } & \multicolumn{7}{c}{ Days } \\
\cline { 2 - 8 } & $\mathbf{1}$ & $\mathbf{2}$ & $\mathbf{3}$ & $\mathbf{4}$ & $\mathbf{5}$ & $\mathbf{6}$ & $\mathbf{7}$ \\
\hline $\mathbf{1}$ & - & - & - & - & - & - & - \\
$\mathbf{2}$ & - & - & - & - & - & - & - \\
$\mathbf{3}$ & - & - & - & - & - & - & - \\
\hline
\end{tabular}

Based on table 4, it is known that contaminant fungi on white bread with steamed treatment stored at refrigerator temperature obtained observations, namely on bread 1, 2, and 3 there was no sign of contaminant fungus growth at all for seven days.

Table 5. Observation of the growth of contaminant fungi on white bread with non-steamed treatment stored at refrigerator temperature

\begin{tabular}{cccccccc}
\hline \multirow{2}{*}{ Breads } & \multicolumn{7}{c}{ Days } \\
\cline { 2 - 8 } & $\mathbf{1}$ & $\mathbf{2}$ & $\mathbf{3}$ & $\mathbf{4}$ & $\mathbf{5}$ & $\mathbf{6}$ & $\mathbf{7}$ \\
\hline $\mathbf{1}$ & - & - & - & - & - & - & - \\
$\mathbf{2}$ & - & - & - & - & - & - & - \\
$\mathbf{3}$ & - & - & - & - & - & - & - \\
\hline
\end{tabular}

Based on table 5, it is known that contaminant fungi in white bread with unsteamed treatment that were 
stored at refrigerator temperature obtained observations, namely on bread 1,2, and 3 there was no sign of contaminant fungus growth at all for seven days.

The results of the frequency distribution of contaminant fungus growth on white bread with steamed treatment can be seen in table 6 . The results of the frequency distribution of the growth of contaminant fungi on white bread with treatment not steamed can be seen in table 7 .

Table 6. Frequency distribution of contaminant fungus growth on white bread with steamed treatment

\begin{tabular}{cccccccc}
\hline \multirow{2}{*}{ Temperature } & \multicolumn{7}{c}{ Days } \\
\cline { 2 - 8 } & $\mathbf{1}$ & $\mathbf{2}$ & $\mathbf{3}$ & $\mathbf{4}$ & $\mathbf{5}$ & $\mathbf{6}$ & $\mathbf{7}$ \\
\hline Room & $0 \%$ & $0 \%$ & $0 \%$ & $33.3 \%$ & $33.3 \%$ & $33.3 \%$ & $66.6 \%$ \\
Refrigerator & $0 \%$ & $0 \%$ & $0 \%$ & $0 \%$ & $0 \%$ & $0 \%$ & $0 \%$ \\
\hline
\end{tabular}

Based on table 6, it is known that the distribution of the growth frequency of contaminant fungi on white bread with steamed treatment stored at room temperature obtained results, namely on the first, second, and third days there was no sign of contaminant fungus growth with a percentage of $0 \%$, on the fourth, fifth, and fifth days. and the sixth growing contaminant fungi with a percentage of $33.3 \%$, on the seventh day growing contaminant fungi with a percentage of $66.6 \%$. The distribution of the growth frequency of contaminant fungi on white bread with steamed treatment stored at refrigerator temperature, ie on the first day to the seventh day was not marked by the growth of contaminant fungi with a percentage of $0 \%$.

Table 7. Distribution of the growth frequency of contaminant fungi on white bread with treatment not steamed

\begin{tabular}{cccccccc}
\hline \multirow{2}{*}{ Temperature } & \multicolumn{7}{c}{ Days } \\
\cline { 2 - 8 } & $\mathbf{1}$ & $\mathbf{2}$ & $\mathbf{3}$ & $\mathbf{4}$ & $\mathbf{5}$ & $\mathbf{6}$ & $\mathbf{7}$ \\
\hline Room & $0 \%$ & $0 \%$ & $0 \%$ & $0 \%$ & $33.3 \%$ & $33.3 \%$ & $33.3 \%$ \\
Refrigerator & $0 \%$ & $0 \%$ & $0 \%$ & $0 \%$ & $0 \%$ & $0 \%$ & $0 \%$ \\
\hline
\end{tabular}

Based on table 7, it is known that the distribution of the growth frequency of contaminant fungi on white bread with treatment not steamed and stored at room temperature obtained results, namely on the first day to the fourth day there was no growth of contaminant fungi with a percentage of $0 \%$, on the fifth to seventh day the contaminant fungus grew. with a percentage of $33.3 \%$. The distribution of the growth frequency of contaminant fungi on white bread with unsteamed treatment stored at refrigerator temperature, ie on the first day to the seventh day was not marked by the growth of contaminant fungi with a percentage of $0 \%$.

\section{DISCUSSION}

Research that has been carried out for seven days of observation, there are differences in the growth of contaminant fungi in white bread stored at room temperature and refrigerator temperature. Bread that was stored at room temperature $\left(27^{\circ} \mathrm{C}-30^{\circ} \mathrm{C}\right)$ with steamed treatment started to grow contaminant fungi on the seventh day on white bread 1 and the fourth day on white bread 2. Bread that was not steamed started to grow contaminant fungi on the fifth day on white bread 2. Bread stored at refrigerator temperature $\left(13^{\circ} \mathrm{C}-\right.$ $16^{\circ} \mathrm{C}$ ) by steaming and not steaming, was not marked by the growth of contaminant fungi from the first day to the seventh day.

Temperature can be related to humidity. Humidity is inversely proportional to temperature, because the higher the temperature, the lower the humidity, and the lower the temperature, the higher the humidity. The statement above is by the results of research that has been done, that the higher the temperature, the lower the humidity, and vice versa (Mizana et al., 2016).

Mold growth is very difficult to prevent. Physical and chemical changes can cause mold growth. Changes that occur can be in the form of partial or complete color changes, changes in texture, changes in aroma, and changes in taste so that the food is not fit for consumption. The fungus that grows on white 
bread can produce mycotoxins during the storage process. Mycotoxins are secondary metabolic products in fungi that can cause poisoning to humans (Lestari et al., 2019).

Aflatoxin is a type of mycotoxin produced by the fungus Aspergillus flavus. Aflatoxins can cause liver cancer in humans. The types of aflatoxins commonly found in food ingredients and processed products are B1, B2, G1, G2. Aflatoxin B1 is the most dangerous aflatoxin than the other aflatoxins. The content of aflatoxins that are acute can damage human body tissues, while those that are chronic can cause liver cancer (Dharmaputra et al., 2013).

This study has advantages over the treatment of white bread by steaming and not steaming. This study still has limitations in the form of a small sample size. In this study, microscopic examination of the growing contaminant fungi has not yet been carried out. Seeing the limitations of this study, it is hoped that in future research it is necessary to add a larger number of samples, and add microscopic methods.

\section{CONCLUSION}

1. Bread overgrown with contaminant fungi at room temperature with steam treatment was $3.33 \%$ on the fourth to fifth day, and $66.6 \%$ on the seventh day.

2. Bread overgrown with contaminant fungi at room temperature with treatment not steamed as much as $3.33 \%$ on the fifth to seventh day.

Suggestion that can be concluded from this research:

1. Researchers hope that future researchers can conduct this research by adding a microscopic examination method.

2. It is recommended for the public to pay more attention to the quality of white bread, if the white bread has changed color, texture, and aroma, it is better not to consume white bread

\section{REFERENCE}

Arena, M. P., et al. 2019. Exploration Of The Microbial Biodiversity Associated With North Apulian Sourdoughs And The Effect Of The Increasing Number Of Inoculated Lactic Acid Bacteria Strains On The Biocontrol Against Fungal Spoilage. Fermentation. 5(97) : 1-21.

Arini, L. D. D. 2017. Faktor-Faktor Penyebab dan Karakteristik Makanan Kadaluarsa yang Berdampak Buruk pada Kesehatan Masyarakat. JITIPARI (Jurnal Ilmiah Teknologi Dan Industri Pangan UNISRI). 2(1) : 15-24.

Asril, M., et al. 2019. Isolasi Cendawan yang Berperan dalam Proses Pembuatan Pliek U (Makanan Fermentasi Khas Aceh). Majalah Ilmiah Biologi Biosfera: A Scientific Journal. 36(1) : 26-34.

BPOM. 2017. Laporan Akhir Tahun BPOM. Jakarta.

Broto, W. 2018. Status Cemaran Dan Upaya Pengendalian Aflatoksin Pada Komoditas Serealia Dan Aneka Kacang. Jurnal Litbang Pertanian. 37 (2) : 81-90.

Dharmaputra, O. S., et al. 2013. Kualitas Fisik, Populasi Aspergillus flavus, dan Kandungan Aflatoksin B1 pada Biji Kacang Tanah Mentah. Jurnal Fitopatologi Indonesia. 9 (4) : 99-106.

Hasanah, U. 2017. Mengenal Aspergillosis, Infeksi Jamur Genus Aspergillus. Jurnal Keluarga Sehat Sejahtera. 15(2) : 76-86.

Hidayat, N., Wignyanto, Sumarsih, S., \& Putri, A. I. 2016. Mikologi Industri. UB Press, Malang.

Indraswati, D. 2016. Kontaminasi Makanan.Forum Ilmiah Kesehatan, Sukorejo.

Indrawati, I., \& Fakhrudin, S. D. 2016. Isolasi dan Identifikasi Jamur pada Air Sumur Dan Air Sungai Di Pemukiman Warga. Biodjati. 1(1) : 27-38.

Kementerian Kesehatan Republik Indonesia. 2018. Lebih dari 200 Penyakit dapat Menular melalui Makanan, Keamanan Pangan Harus Diperhatikan. https://www.kemkes.go.id/article/view/18092700003/lebih-dari-200-penyakit-dapat-menular-melaluimakanan-keamanan-pangan-harus-diperhatikan.html. (Accessed: 2 Juli 2021).

Khasanah, H. N., et al. 2013. Studi Tentang Pengaruh Lama Penyimpanan Terhadap Keanekaragaman Kapang Kontaminan Pada Tepung Terigu. Seminar NasioNal X Pendidikan Biologu FKIP UNS. 1-5

Lestari, A. D., et al. 2019. Identifikasi Jamur Pada Roti Yang Dijual Di Kota Langsa Berdasarkan Lama Penyimpanan. Journal Jeumpa. 6(2) : 245-256.

Mizana, K. D., et al. 2016. Identifikasi Pertumbuhan Jamur Aspergillus Sp pada Roti Tawar yang Dijual di 
Kota Padang Berdasarkan Suhu dan Lama Penyimpanan. Jurnal Kesehatan Andalas. 5(2) : 355-360

Natawijaya, D., et al. 2015. Uji Kecepatan Pertumbuhan Jamur Rhizopus Stolonifer dan Aspergilus Niger yang Diinokulasikan pada Beberapa Jenis Buah Lokal. Siliwangi. 1(1) : 32-40.

Petruzzello, M. 2013. Rhizopus Fungus genus. https://www.britannica.com/science/Rhizopus (Accessed: 16 Desember 2020).

Purwantisari, S. \& Hastuti, R. B. 2009. Isolasi dan Identifikasi Jamur Indigenous rhizosfer Tanaman Kentang dari Lahan Pertanian Kentang Organik di Desa Pakis, Magelang. Bioma: Berkala Ilmiah Biologi. 11(2) : 45-53.

Pusuma, D. A.,et al. 2018. Karakteristik Roti Tawar Kaya Serat Yang Disubstitusi Menggunakan Tepung Ampas Kelapa Jurnal Agroteknologi. 12(01) : 29-42.

Rahayu, W. P., \& Nurwitri, C. C. 2012. Mikrobiologi Pangan. IPB Press, Bogor.

Ratnawati, et al. 2016. Identifikasi dan Penentuan Jenis Cendawan Yang Menginfeksi Kulit Pasien Balita di Rumah Sakit Umum Pusat Haji Adam Malik Medan. Jurnal Biologi, Lingkungan, Industri, Kesehatan. 2(2) : 90-99.

Ravimannan, N., et al. 2016. Study On Fungi Associated With Spoilage Of Bread. International Journal of Advanced Research in Biological Sciences. 3(4) : 165-167.

Riyanto, A. 2019. Aplikasi Metodologi Penelitian Kesehatan. Mulia Medika, Yogyakarta.

Roosheroe, I., et al. 2014. Mikologi Dasar dan Terapan. Yayasan Pustaka Obor Indonesia, Jakarta.

Sitanggang, A. B. 2017. Faktor Kerusakan Produk Bakeri dan Pengendaliannya. Foodreview Indonesia. $12(2): 40-44$.

Smith, A., \& Hursepuny, A. 2015. Isolasi dan Identifikasi Jenis Jamur Pada Ubi Kayu (Manihot esculenta crants.) Dalam Proses Pembuatan Ubi Kayu Hitam Secara Tradisional Oleh Masyarakat Banda. BIOPENDIX: Jurnal Biologi, Pendidikan Dan Terapan. 1(2) : 161-165.

Sulastina, N. A. 2020. Analisis Jamur Kontaminan Pada Roti Tawar Yang Dijual Di Pasar Tradisional. Jurnal Aisyiyah Medika. 5(1): 122-130.

Unachukwu, M. N., \& Nwakanma, C. 2015. The Fungi Associated With The Spoilage Of Bread In Enugu State. International Journal of Current Microbiology and Applied Sciences. 4(1) : 989-995.

Unit, M. P. T. 2003. Mucor, a Most Destructive Mold. https://www.moldunit.com/mucor-mold.html (Accessed: 20 Desember 2020).

Vagelas, I., et al. 2011. Bread Contamination With Fungus. Carpathian Journal of Food Science and Technology. 3(2) : 1-6.

World Health Organization. 2019. 23 million people falling ill from unsafe food each year in Europe is just the tip of the iceberg. https://www.who.int/news/item/05-06-2019-23-million-people-falling-ill-fromunsafe-food-each-year-in-europe-is-just-the-tip-of-the-iceberg. (Accessed: 2 Juli 2021). 